\author{
Krzysztof Lewandowski \\ dr inż. \\ Politechnika Wrocławska \\ Zespół Eksploatacji Systemów Logistycznych i Transportowych \\ Katedra Eksploatacji Systemów Technicznych \\ krzysztof.lewandowski@pwr.edu.pl
}

DOI: 10.35117/A_ENG_20_05_03

\title{
Toilet in the train
}

\begin{abstract}
The aim of this article is analyze of usage solution of the toilets in the trains and show of the law regulation how many of the toilets should be in of the train. The article discusses the problem of the number of toilets in trains and the level of maintenance. It is noted that this should not depend on the will of the local government contracting authority, as it has been so far, but should result from the provisions. The problem of the technical standard of the toilet, which would allow for greater convenience for passengers, was also raised.
\end{abstract}

Keywords: Toilet, Rail car, Maintenance

\section{Introduction}

The toilet on the train is one of the oldest technical devices in passenger trains in order to ensure the comfort of passengers while traveling. The subject of toilets is not often analyzed due to the fact that it is a slightly embarrassing topic, but also little technical progress in this matter. The article presents an analysis of the used solutions of toilets in trains in Poland in terms of user-passenger friendliness and reliability of the technical solutions used in them. Additionally, a statistical analysis of the number of people per toilet was performed, as well as a proposal of legal regulations in this regard.

\section{A brief look at the history}

The first railway car, the "Victory" (Fig. 1), fitted with a flush toilet, entered the tracks in 1836 (!) On the Philadelphia and Germantown Railroad in the USA [3]. Its designer was Richard Imlay (born October 9, 1784, Hartford CT - died March 20, 1867, New York City NY, USA) [1]. The wagon was built on a U-shaped wooden frame. Under the raised ends of the frame, torsion bogies for two-wheel axles, patented in 1837, were suspended on leaf springs under the wagon frame [20]. Above them, at the ends of the car, there was a bar and, on the opposite side, a separate washroom cabin with running water and a cabin with an open toilet, i.e. faeces falling onto the tracks. This car was highly appreciated by passengers and in the same year, the company ordered three more cars of this type, each for $\$ 1,600$. The wagons were: $10.97 * 2.8 * 3.97 \mathrm{~m}$ (long 36 feet long, 9 feet, $21 / 2$ inches wide, and 13 feet, 1/3inch high). They became a model for Pullman wagons, which imposed a new model of wagons in the world [2][22][23]. 


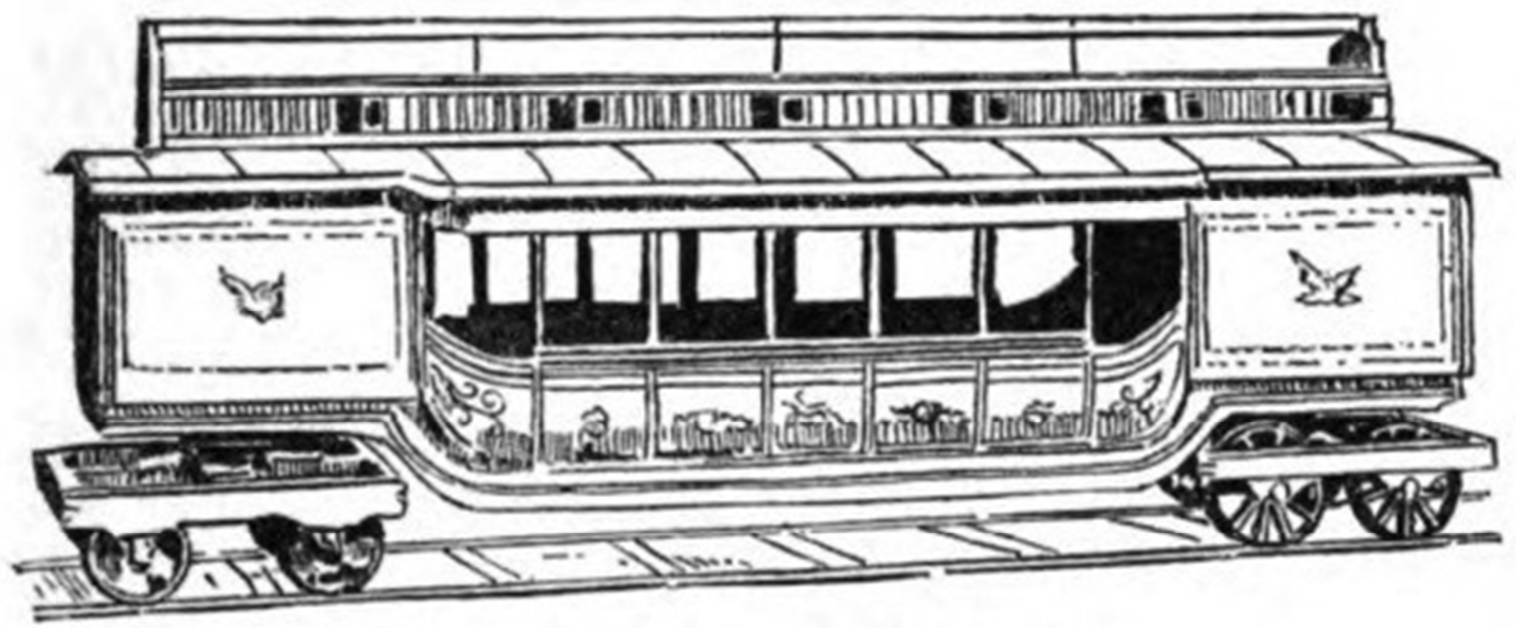

1. Richard Imlay's sketch - "Victory" wagon from 1836 [22]

Soon, passenger carriages were built, the design of which had not been substantially changed for almost 100 years. Although the carriages increased their dimensions (Fig. 2), which was related to the replacement of timber for load-carrying structures with iron, their functional arrangement was the same. Central or side corridor, with or without a compartment, passenger compartment and at the ends, when passing to adjacent carriages, bathrooms (Fig. 3).

\begin{tabular}{|c|c|c|c|}
\hline Jahr. & Darslellung der Länge und Zusammeastellumg der Züge. & ${ }^{2}=$ & \\
\hline 1840 & Lencolymang & so & 30 \\
\hline $18 s 0$ & 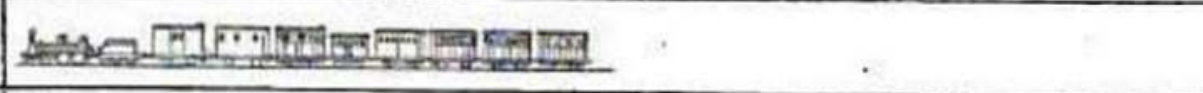 & 90 & 42 \\
\hline 1860 & 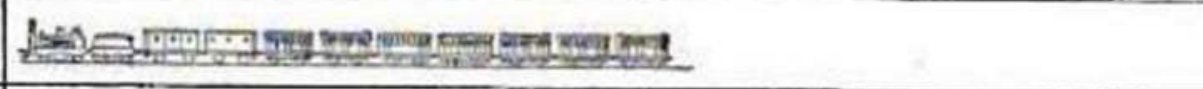 & 110 & 48 \\
\hline 1870 & Lime & 170 & s6 \\
\hline 1880 & 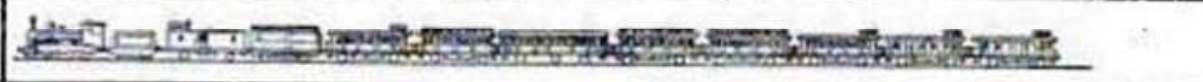 & 200 & 60 \\
\hline 1890 & 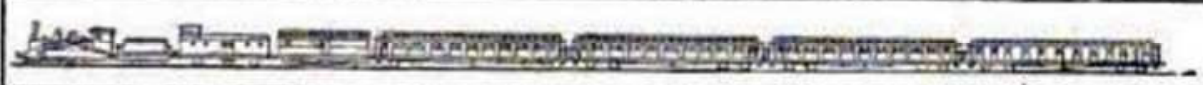 & 280 & 70 \\
\hline
\end{tabular}

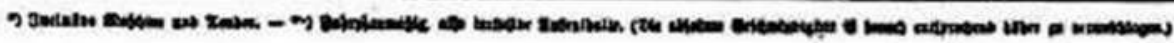

2. Increase in the size of passenger trains in the period 1840-1890 [7] 

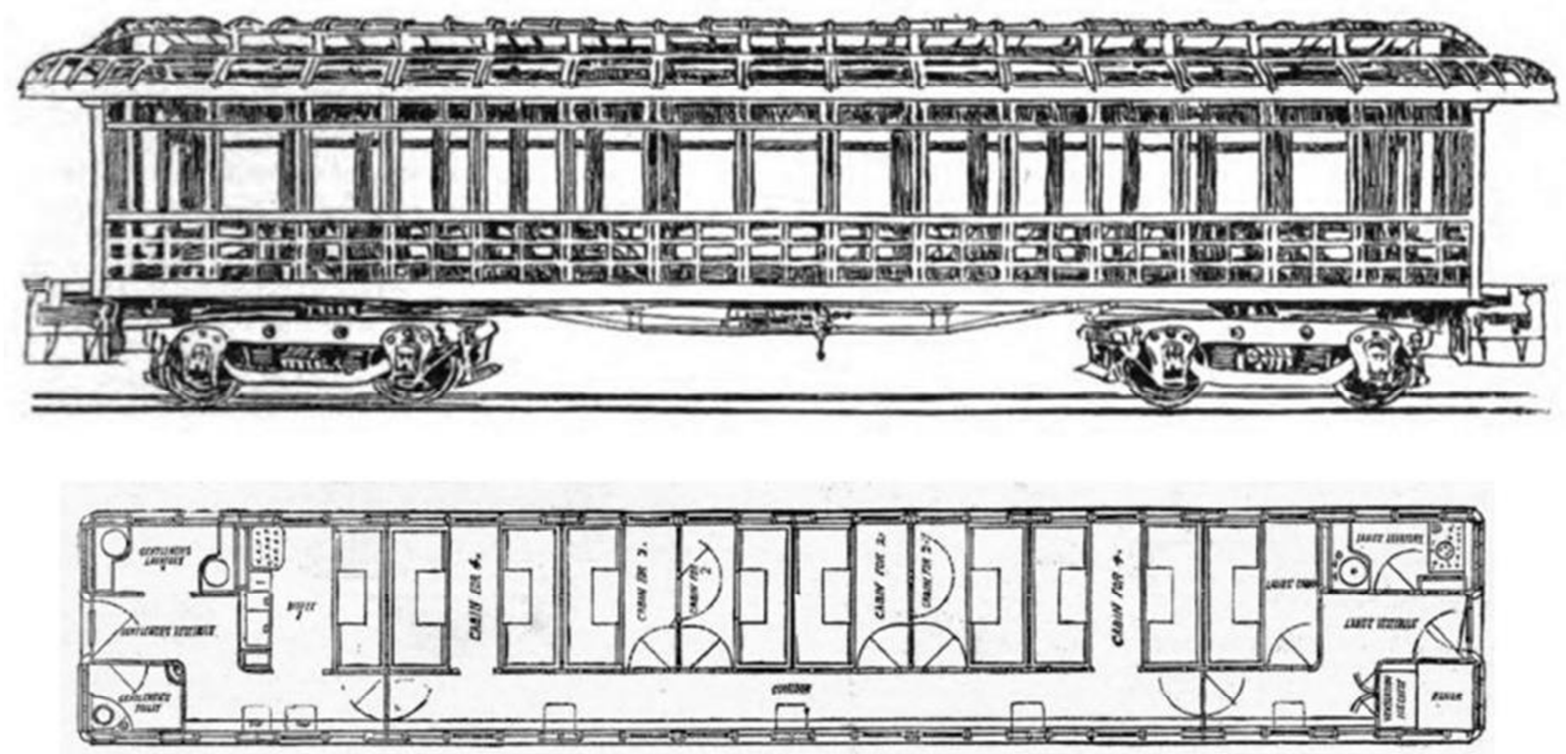

3. The frame and interior layout of a passenger wagon from 1888 [3][22]

The development of an electric and internal combustion engine in the second half of the 19th century resulted in the appearance of small rail vehicles known today as railbuses (Fig. 4-5). Their interior layout was similar to classic railway carriages. Their interior layout also included one open-type toilet (Fig. 6-7). Toilets were not installed in small local vehicles, for short journeys or in trailers only (Fig. 8).

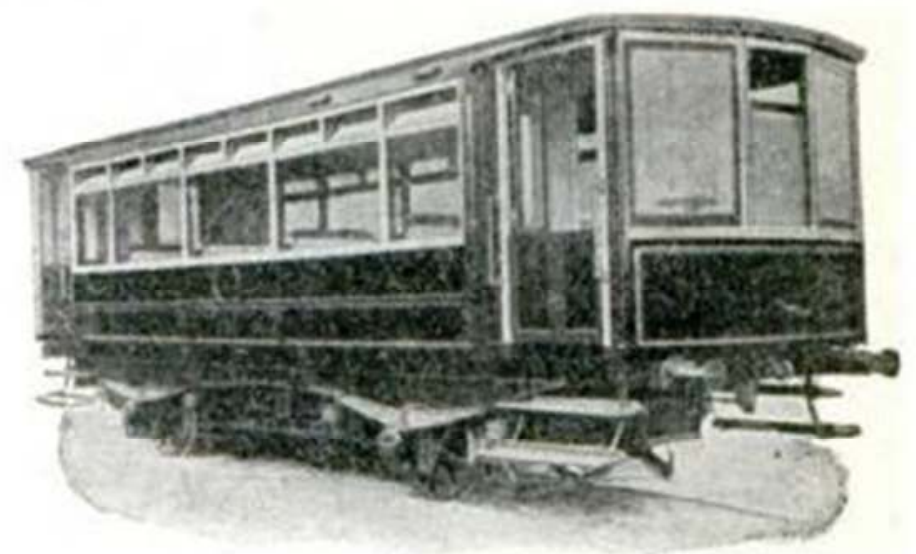

4. Great Northern Railway of England motor carriage from 1904 [13]

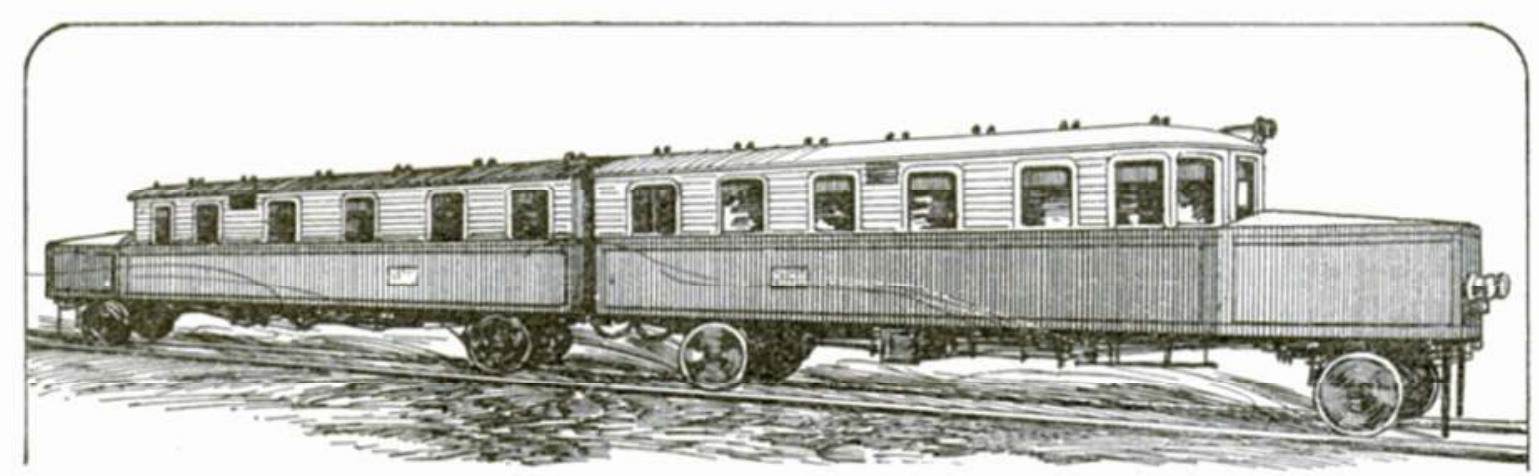

5. Wittfeld's vehicle from 1909 [14] 


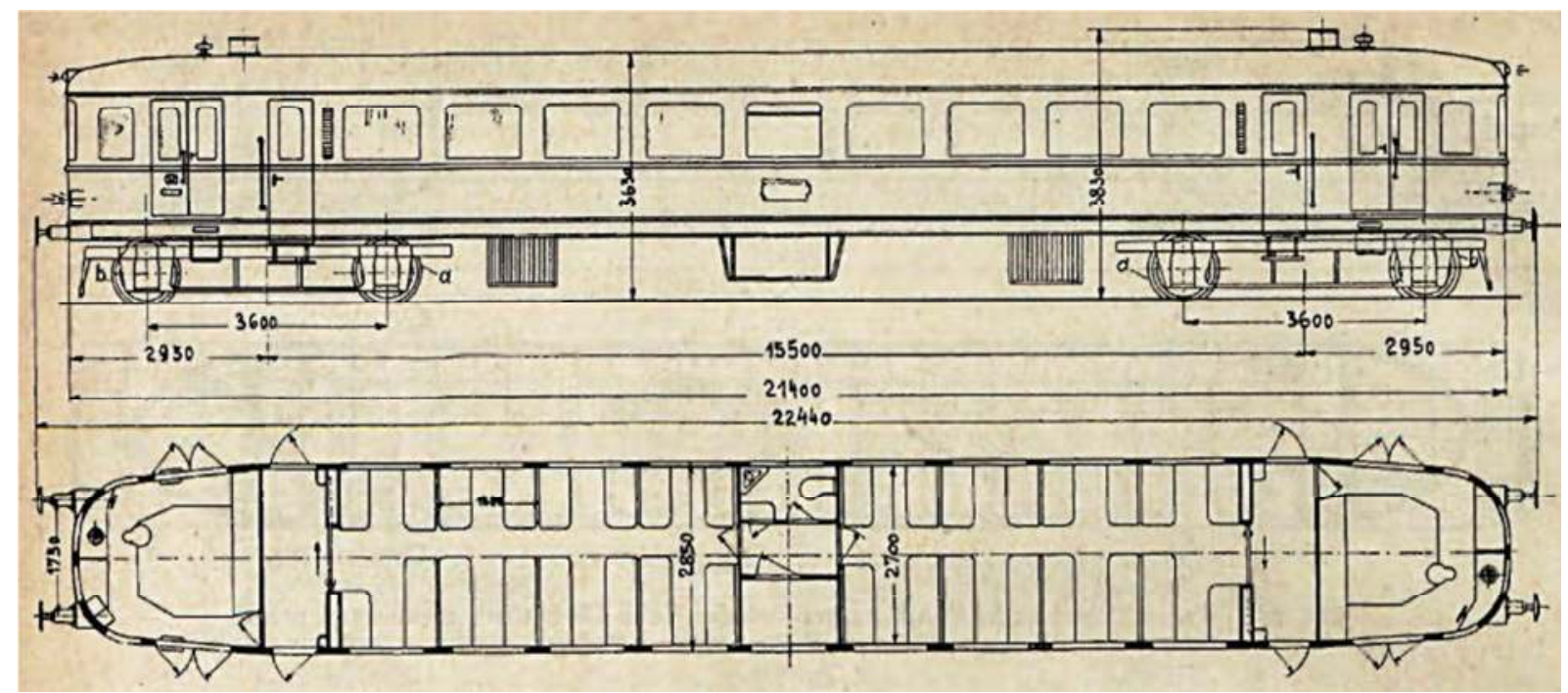

6. Simmering Gebus diesel electr wagon built in Huta Królewska and Laura [11]

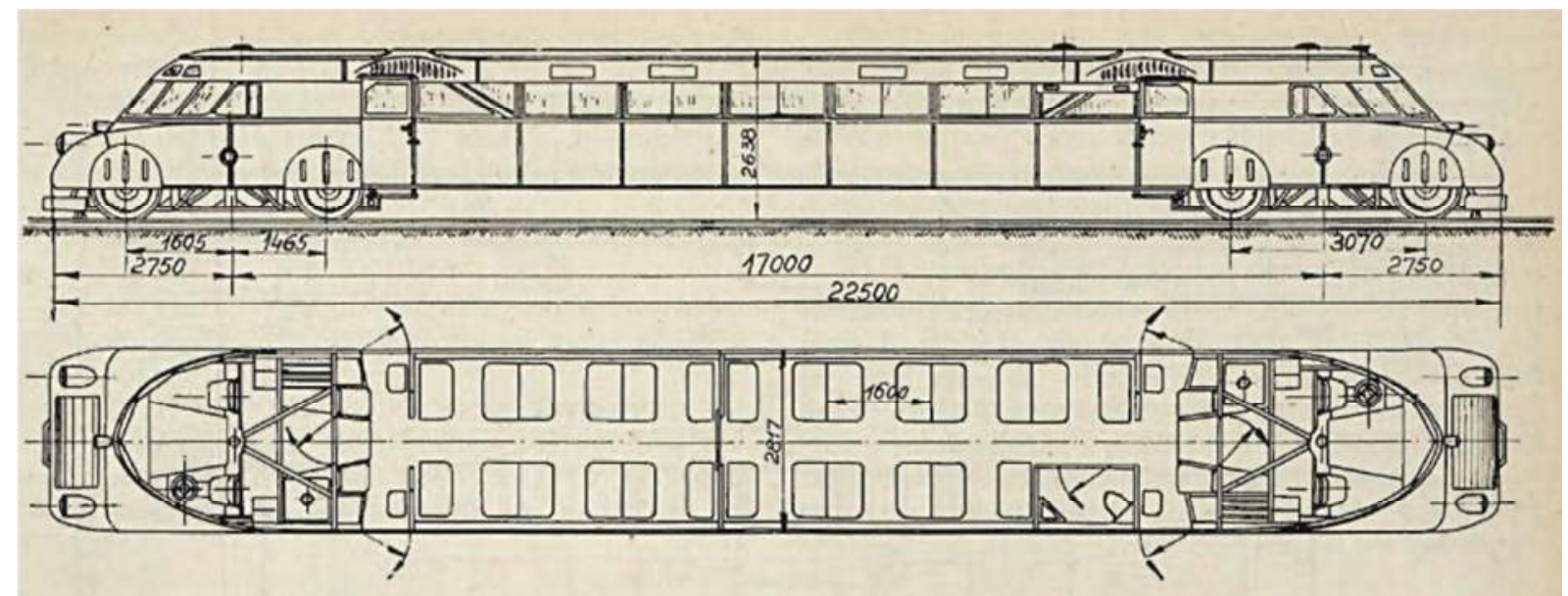

7. Diesel-hydr. (MAN-Austro-Daimler-Voith-Chrzanów), Lux-Torpeda built by the First Locomotive Factory in Poland [11].

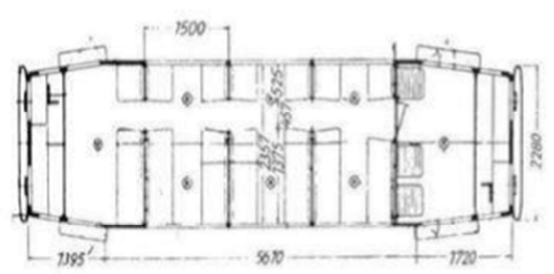

Kleintriebugen mit 6.5 PS-Dieselmotor (32. Xitsplät:r)

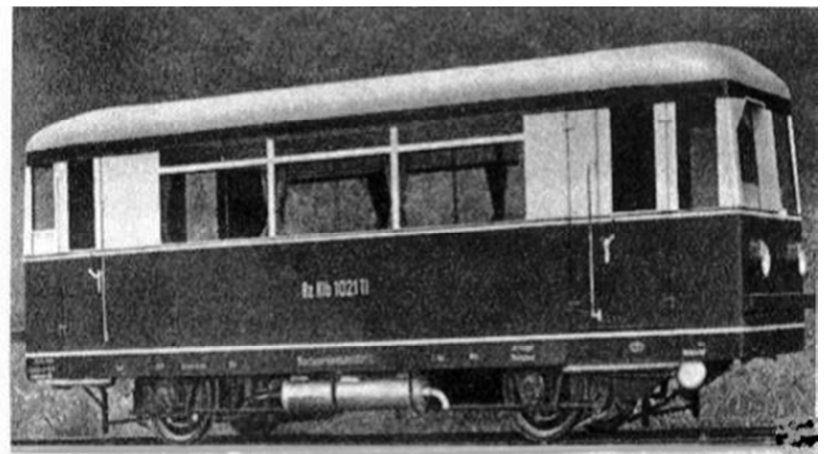

Goerlitz 1934 used on the Mirsk - Świeradów railway line [9]

\section{Selected solutions used in toilets in trains in Poland}

Currently, Polish railway carriers use various types of a rolling stock equipped with toilets. These are classic wagons, electric and diesel multiple units, and a new hybrid from Newag 36Weh on Polish tracks..

Classic rail cars are rail vehicles without their own drive intended to be included in a train pulled by a locomotive (steam, diesel, electric or hybrid). Electric multiple units are self- 
propelled multi-unit combined vehicles in the form of electric motors with an appropriate starting system. Combustion traction vehicles are single or multi-unit self-propelled vehicles in the form of an internal combustion engine with direct drive transmission to driving axles or by means of various types of mechanical or electrical transmissions. They are popularly called rail buses. Toilets are installed in all these rail vehicles. What this article will focus on are the problems associated with

- user-passenger friendliness and

- reliability of the solutions used in them.

Interestingly, most of them concern new trains, i.e. those with a closed toilet.

The smallest active vehicle is a two-axle motor car of the 810 series (series M152.0), popularly known as the motor-driver, which enters Polish tracks from the Czech Republic and Slovakia [21] (Fig. 9). The maximum number of passenger seats is 95 [24]. This wagon has a classic open toilet with a door closed in the form of a rotary bolt lock. An interesting fact is that there is a hook for hanging the toilet seat next to the toilet bowl so that it does not become contaminated, due to the small space to go up (Fig. 10).

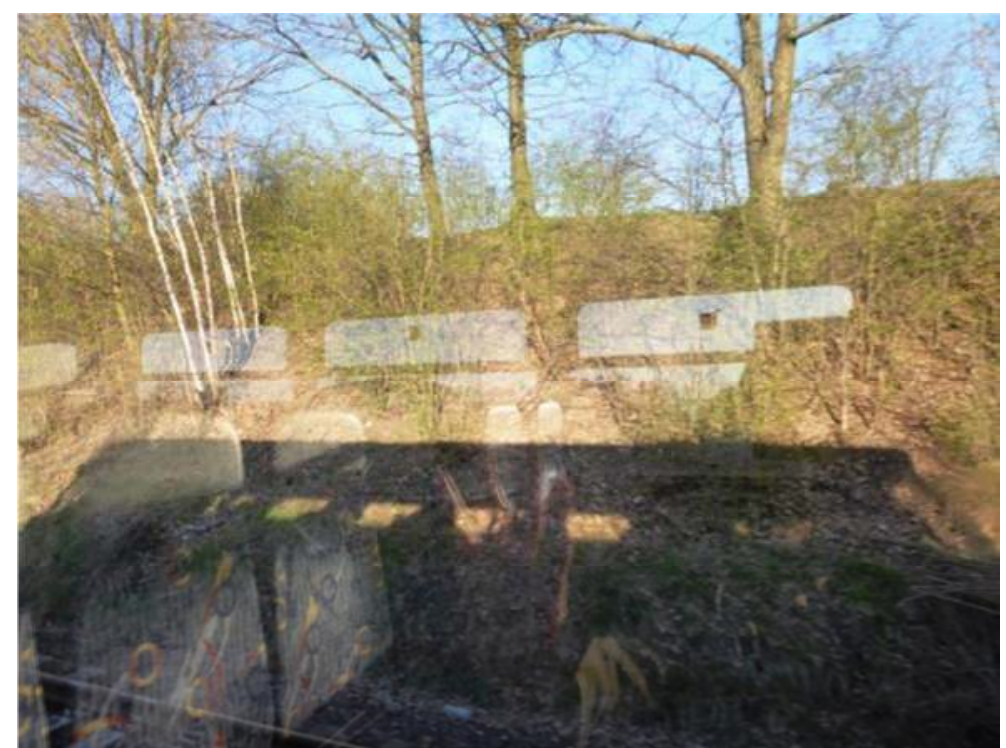

9. Motoraczek from the window on the route Sẹdzisław - Kralovec

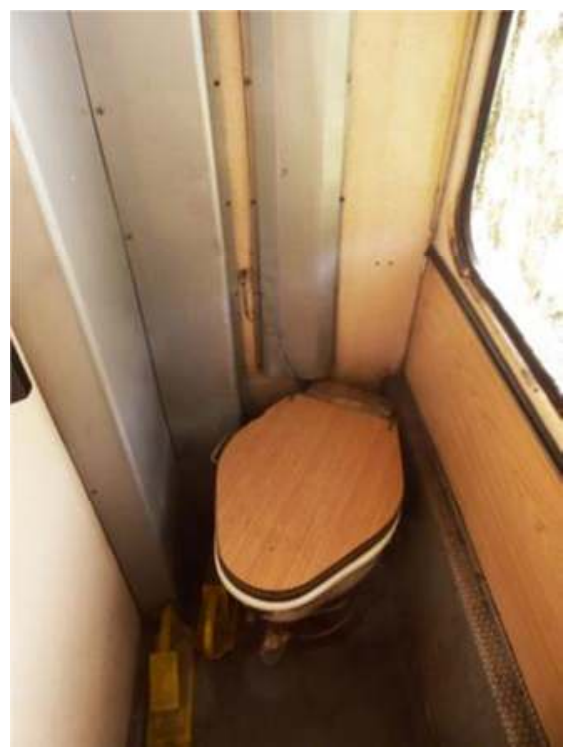

10. Toilet in motoraczek 
A slightly larger two-axle vehicle is the Regio Tramp by ZNTK Poznan, marked as the SA 105 and SA 108 series (Fig. 11). This vehicle is equipped, depending on the version $(213 \mathrm{M}, 213 \mathrm{Ma}$, and $215 \mathrm{M})$, with a small or large toilet cubicle. The maximum number of passenger seats is 90 and 205 (198) [5] [6]. The toilet cubicle has a classic rotary bolt lock to lock the door. The toilet is a closed system.

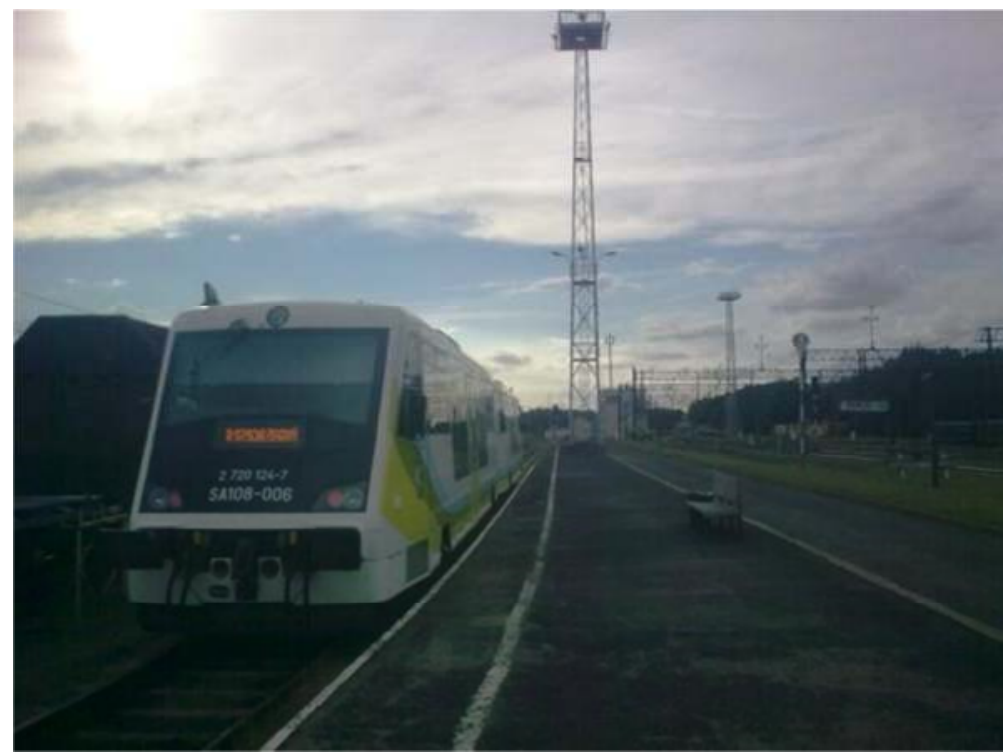

11. Regio Tramp in Żagań

Another vehicle is PESA 214M (series SA103, SA106, SA135) produced by PESA Bydgoszcz. It is a two-axle vehicle (Fig. 12). The maximum number of passenger seats is approximately 120 . The vehicle has one toilet [18]. The toilet cubicle has a classic rotary bolt lock to lock the door. The toilet is a closed system (fig. 13-14).

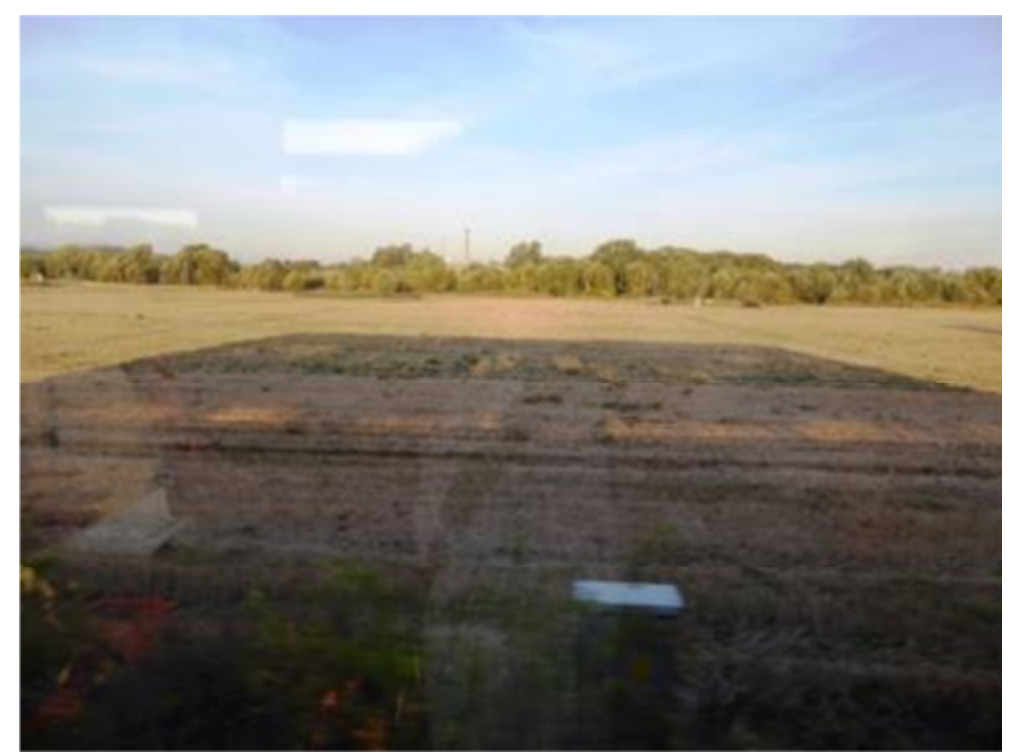

12. Koleje Dolnośląskie PESA SA134-002 in Kotlina Kłodzka 


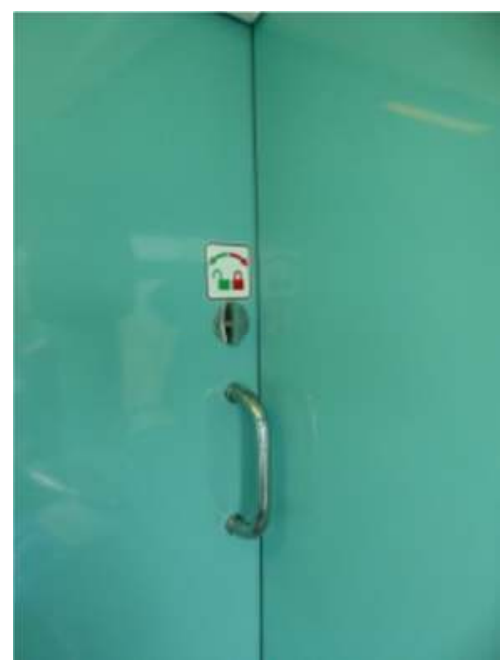

13. SA135 and SA134 toilet door lock

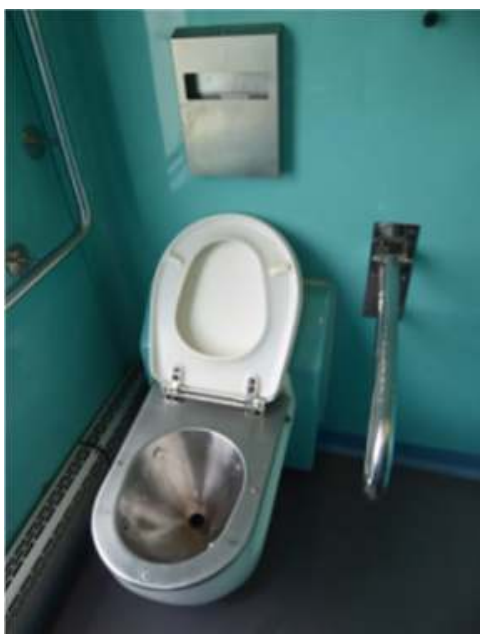

14. Toilet in SA 135 and in SA134

The larger vehicle is the two-unit Pesa $218 \mathrm{M}(218 \mathrm{Ma}, 218 \mathrm{Mb}, 218 \mathrm{Mc}, 218 \mathrm{Md}$ (SA109, SA131, SA133, and SA 134 series) produced by PESA Bydgoszcz.

It is a two-axle articulated vehicle mounted on three two-axle bogies, including a Jakobs middle bogie. The maximum number of passenger seats is about 290 [12]. The vehicle has one toilet identical to the SA 135 . The toilet cabin has a classic rotary bolt lock to lock the door. The toilet has a closed system.

The development is the PESA Link type 223M, SA 139 series vehicle. These are two, three, or even four-unit diesel rail vehicles. The toilet cubicle has a classic rotary bolt lock to lock the door. The toilet is a closed system [10].

The larger vehicle is the PESA Atribo type 219M, series SA136 (Fig. 15). It is a threeunit vehicle seated on four bogies, including two Jakobs. Extreme carriages are driving. The maximum number of passenger seats is approximately 304. The vehicle has two toilets. Including one for disabled people. Both toilets have a closed system. The toilet doors have classic rotary bolt locks for locking (Fig. 16-17) [19]. 


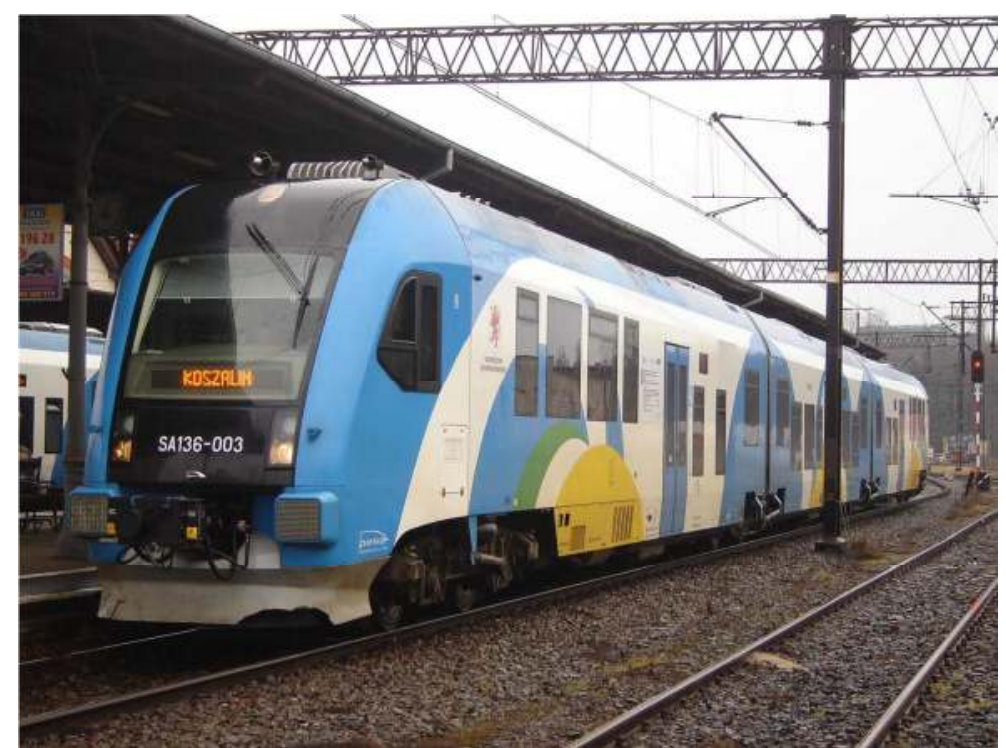

15. SA 136-001 of the Marshal's Office of the West Pomeranian Voivodeship [19]

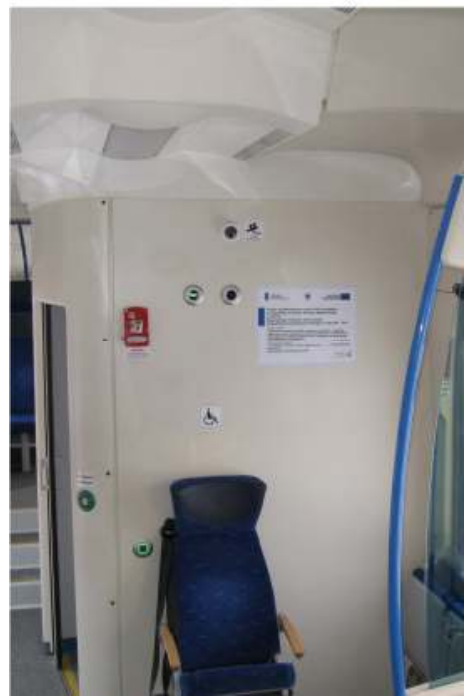

16. Toilet door for the disabled in SA136 of the Marshal's Office of the West Pomeranian Voivodeship [19]

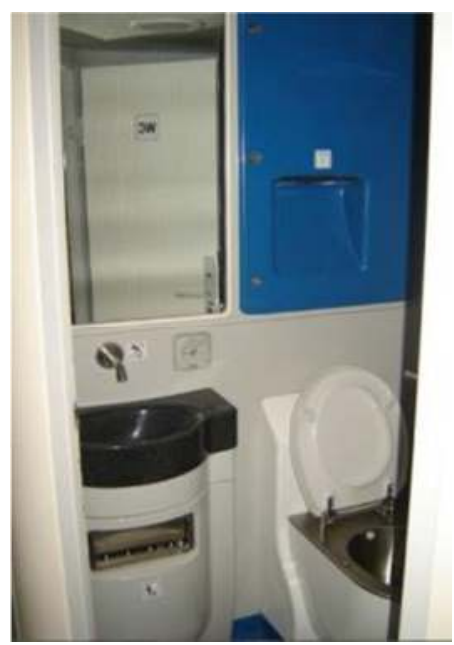

17. Toilet in SA136 of the Marshal's Office of the West Pomeranian Voivodeship [19] 
The NEWAG 220/221 vehicles (SA137, SA138 series) are similar (Fig. 18). They are manufactured as two or three-unit vehicles. It is a three-unit vehicle seated on three (Sa137) or four (SA138) bogies, including two Jakobs. Extreme carriages are propulsive. The maximum number of passenger seats is approximately 390. The vehicle in both configurations has only one toilet in a closed system (Fig. 19)[17].

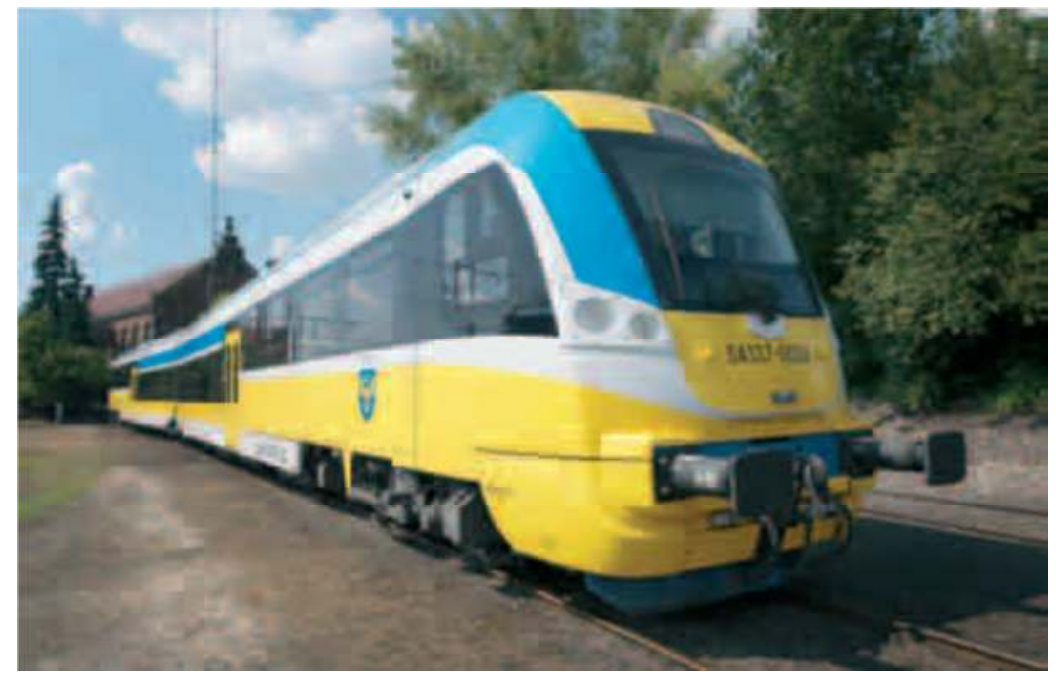

18. SA 137 of the Marshal's Office of the Opolskie Voivodeship [17]

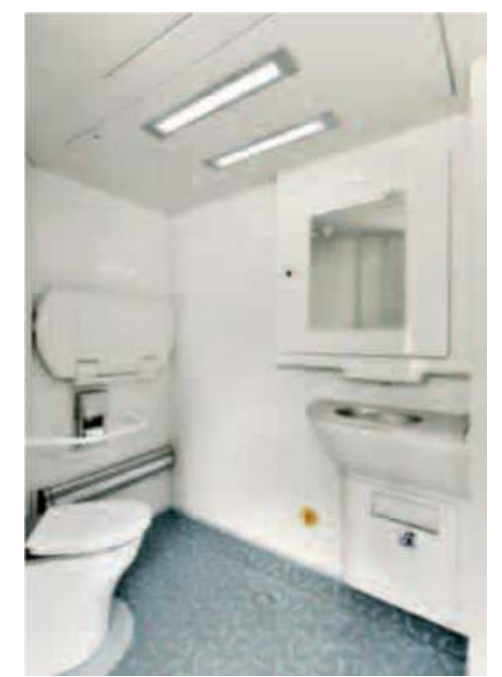

19. Toilet in SA137 of the Marshal's Office of the Opolskie Voivodeship [17]

3 -section vehicles are bigger. They are equipped with 1 or 2 toilets on board. The PAFaWag EN57 vehicles (popularly known as the bucket of railway enthusiasts) and NEWAG36We (Fig. 20) are shown as examples. In the oldest EN57 vehicle, the toilet is open, i.e. faeces fall onto the track (fig. 21-22). In newer vehicles, the toilet is closed, i.e. the faeces are collected in the tank.

The vehicles of the manufacturer NEWAG are equipped with various toilet closing systems. It is an electronic lock locked (?) With a button and mechanical closures with a rotary bolt (Fig. 23-26). In the version for ŁKA (Łódzka Kolej Aglomeracyjna - 36Wed), the manufacturer installed the most readable toilet closing system in its offer (Fig. 27). 


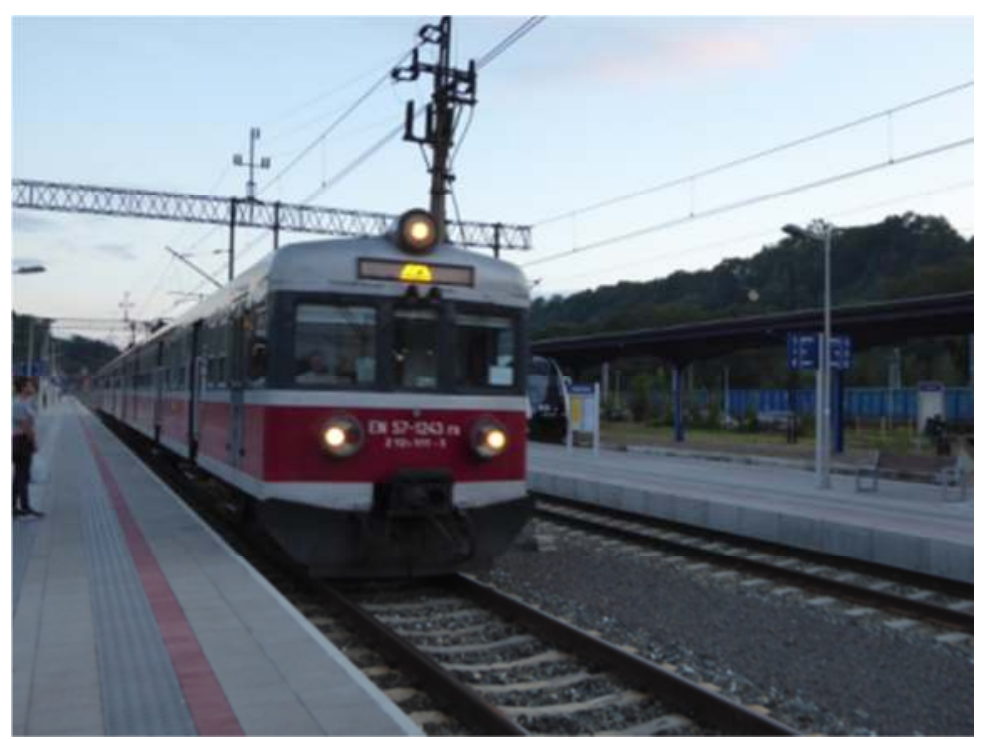

20. EN57-1243ra in Kłodzko Główne

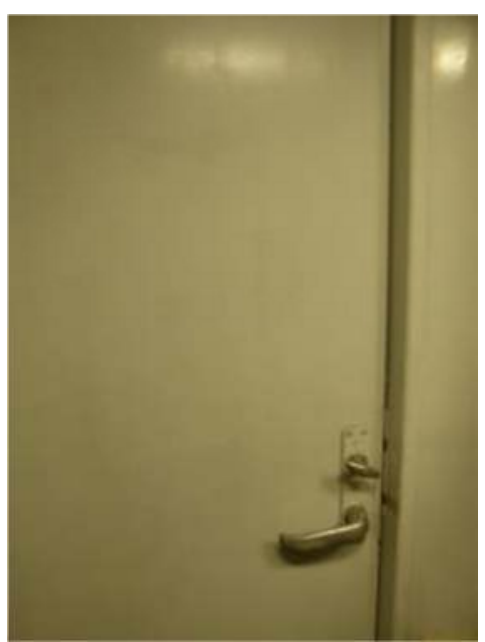

21. EN57-1243ra toilet door

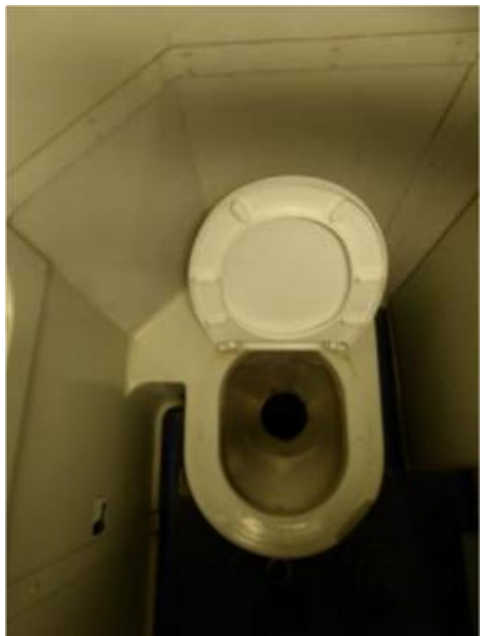

22. Toilet in EN57-1243ra 


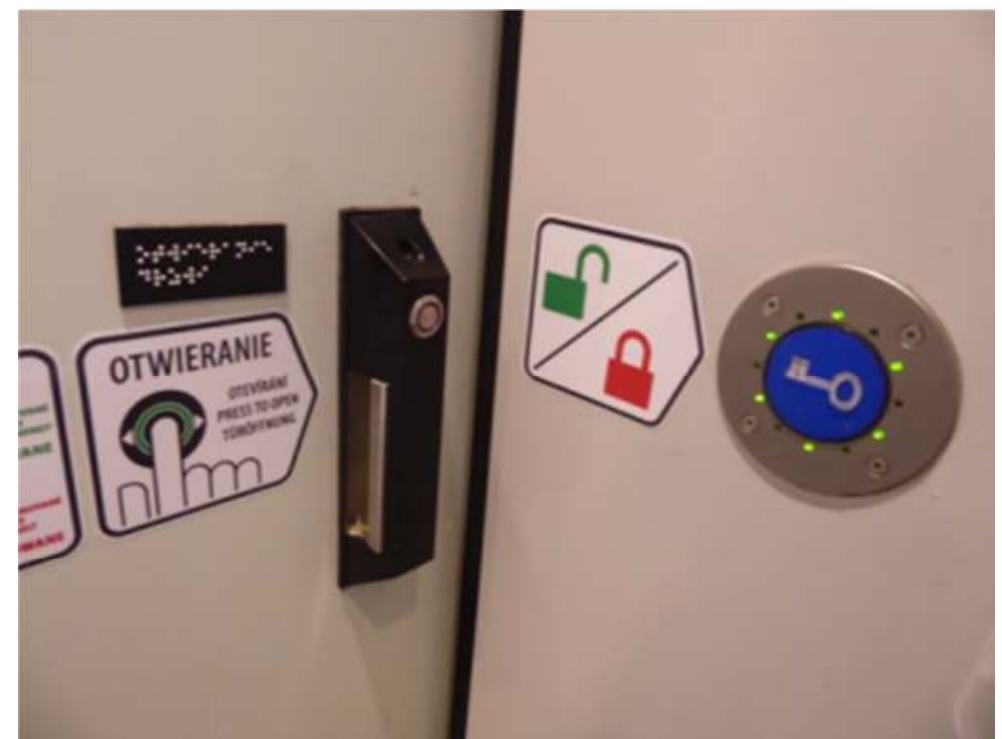

23. Mechanically locked lock with electric door opening

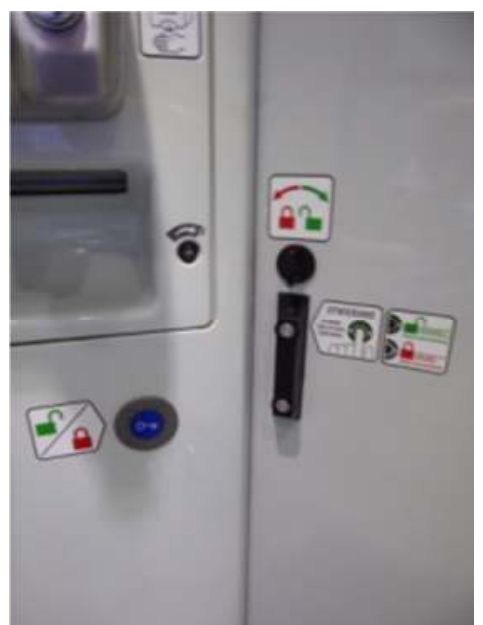

24. Lock with a mechanical and electronic lock, mechanical with electric door opening

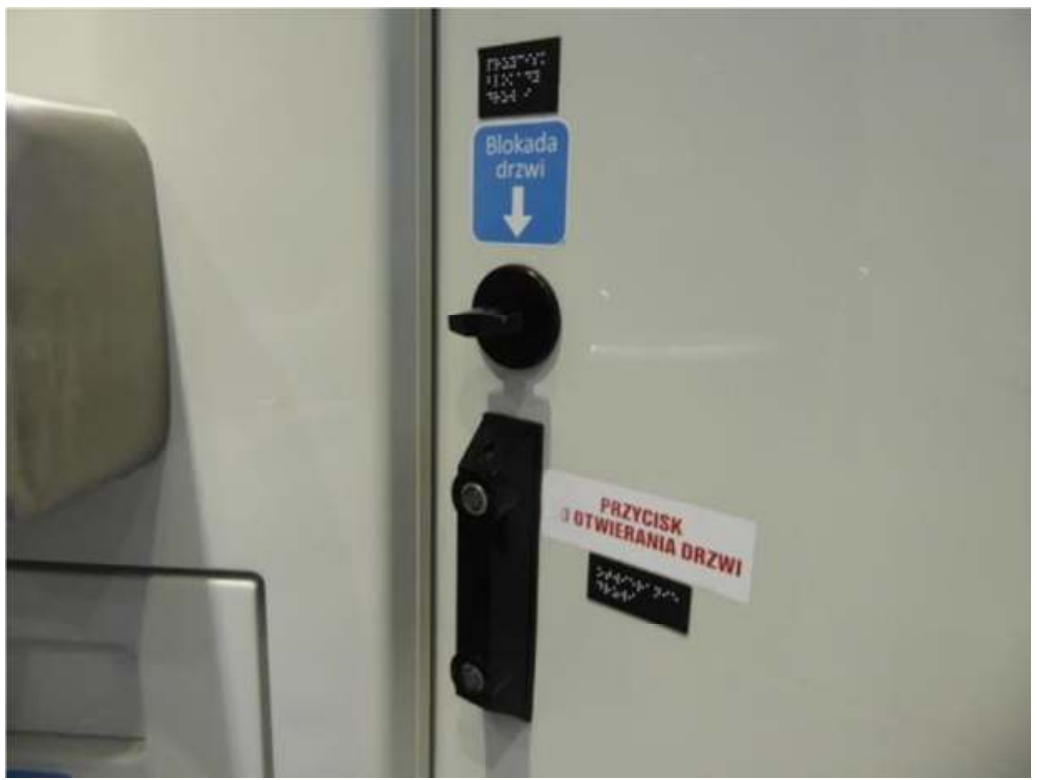

25. Mechanically locked lock with electric door opening 


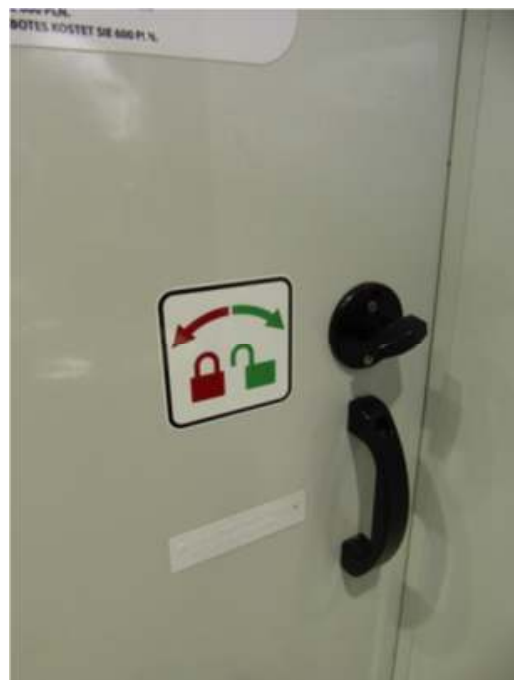

26. Lock with mechanical interlock and manual door opening

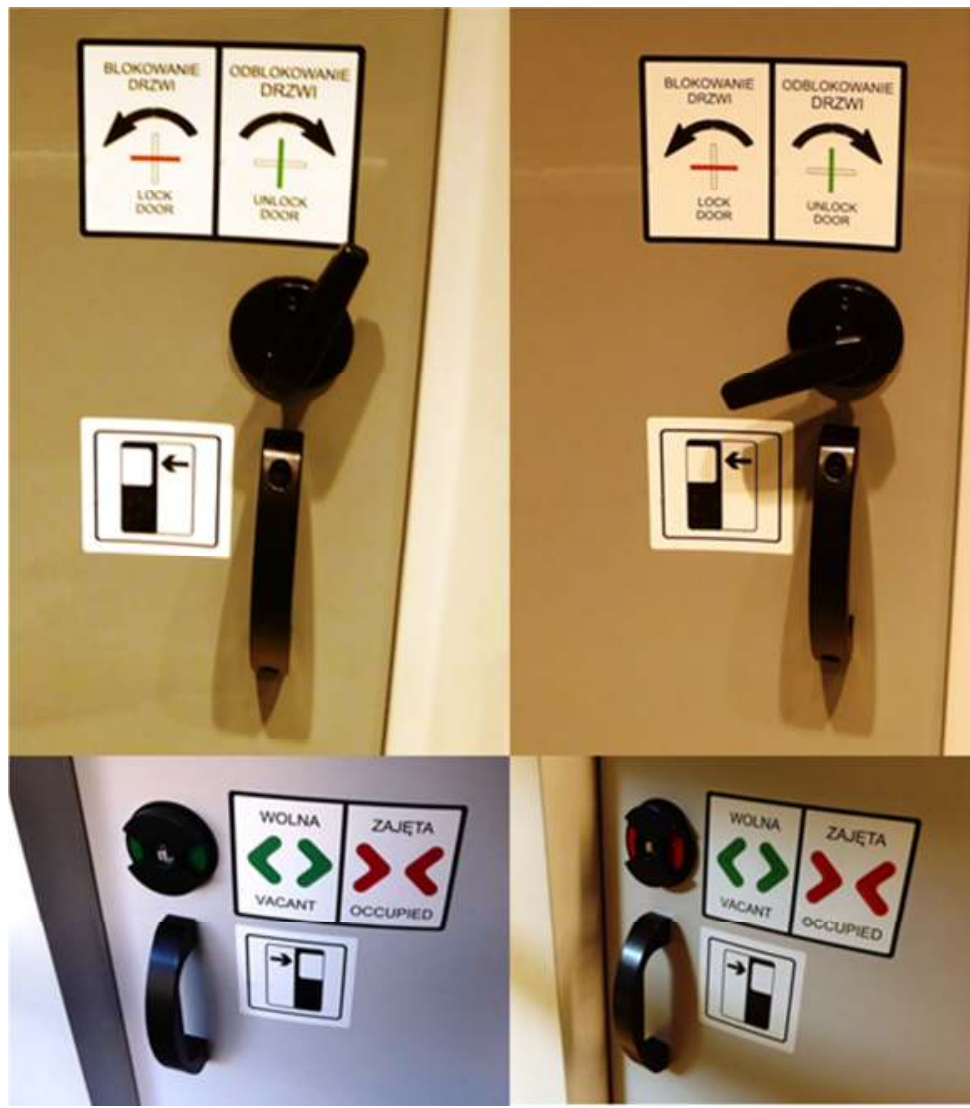

27. The most readable toilet lock on the ŁKA train, view from inside the toilet and from outside with open and closed lock

In vehicles larger than 4 units, such as the EZT trains used in Poland by PKP Intercity, there are several toilets with a mechanical lock (Fig. 28). Another carrier, Pol-Regio, i.e. the old Przewozy Regionalne, runs both EZT trainsets and trains consisting of classic carriages and locomotives (Fig. 29). Koleje Mazowieckie and others run similar trains. In classic carriages, the number of toilets has been reduced to one per car, but they have classic mechanical locks It is worth knowing that the number of toilets does not reflect into their availability. When passing in an IC class train, when the photo was taken (Fig. 28), only two out of seven toilets were operational. 


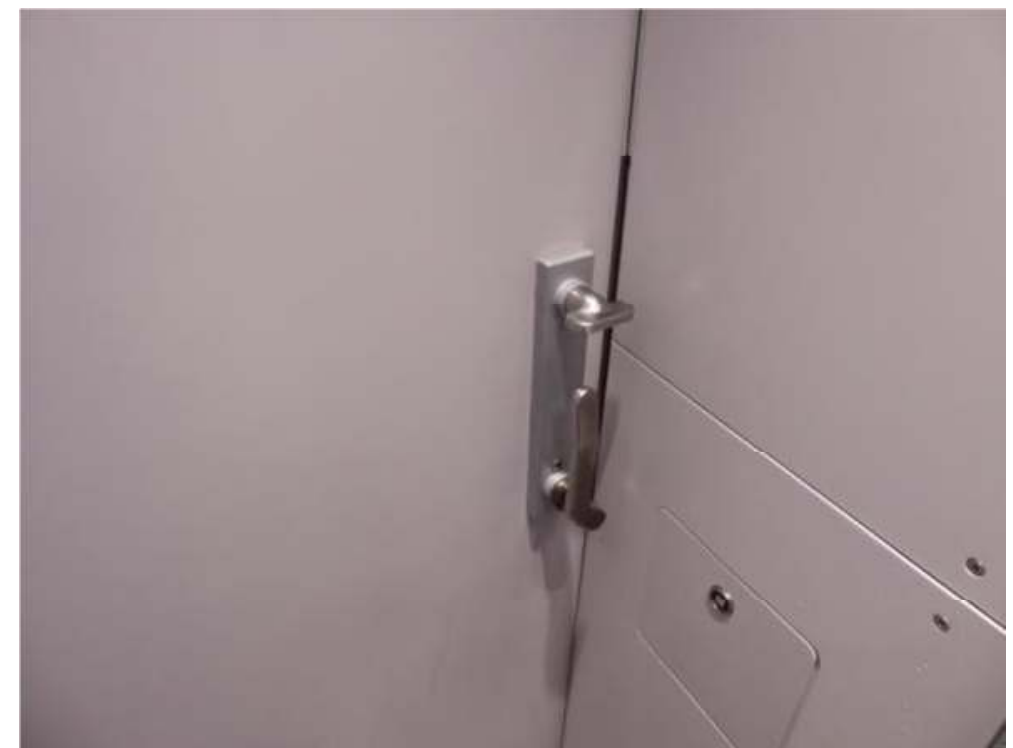

28. Lock with mechanical interlock and manual door opening in PKP Intercity train station

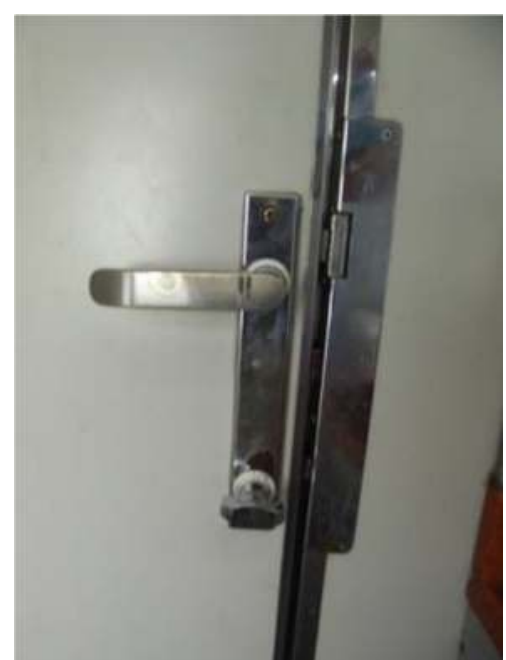

29. Lock with mechanical interlock and manual door opening in the Pol-Regio warehouse

\section{Problems of using toilets in trains on the example of Lower Silesia}

Contrary to popular belief, the modern toilet is a complicated technical device, not a toilet bowl with an opening in the floor of the wagon, in which there is nothing to break. Thus, there are many components that can get damaged and prevent the use of this device.

The basic problem is the huge sensitivity of the toilet bowl emptying structure to what goes into it. This clogs the suction pipe and fills the toilet bowl (fig. 30). Without going into detail, many passengers treat the train toilets the same way as they do at home. So as a garbage can. Items not related to personal hygiene go there. But the personal care items themselves pose problems. Due to the fact that the passenger will not throw them into the trash bin, which is in every toilet, but into the toilet bowl - the suction hose is clogged. The toilet manufacturer provides for the possibility of cleaning them by applying increased pressure when the door is blocked. For this purpose, the train crew, driver, or manager or conductor should press a special button to start the cleaning procedure. But here it is worth pointing out that only once in 44 train journeys in Lower Silesia, the train staff responded to a passenger signal that the toilet was clogged. After 2 minutes of the purge process with increased pressure, the toilet was unobstructed and functional. A separate matter is the emptying of toilet faeces tanks by the carrier. There is nothing more annoying when a 
passenger gets on a train at the starting station, e.g. in Wrocław to Szklarska Poręba Górna that is, for a 3-hour drive, where there is one and only toilet and it is clogged. The train manager explains that he received such an order from the dispatcher. It would be worthwhile for carriers to agree on this, despite competition for passengers. Koleje Dolnośląskie KD has a toilet service in Legnica and Wrocław. Meanwhile, each night several KD train sets, and not only, spend the night at the end stations in Lower Silesia. Carriers can, thanks to a group contract, hire sanitation companies from the regions of these stations to empty, wash and fill the water and soap tanks in the toilets in their depots. This would significantly improve passenger service and corporate image.

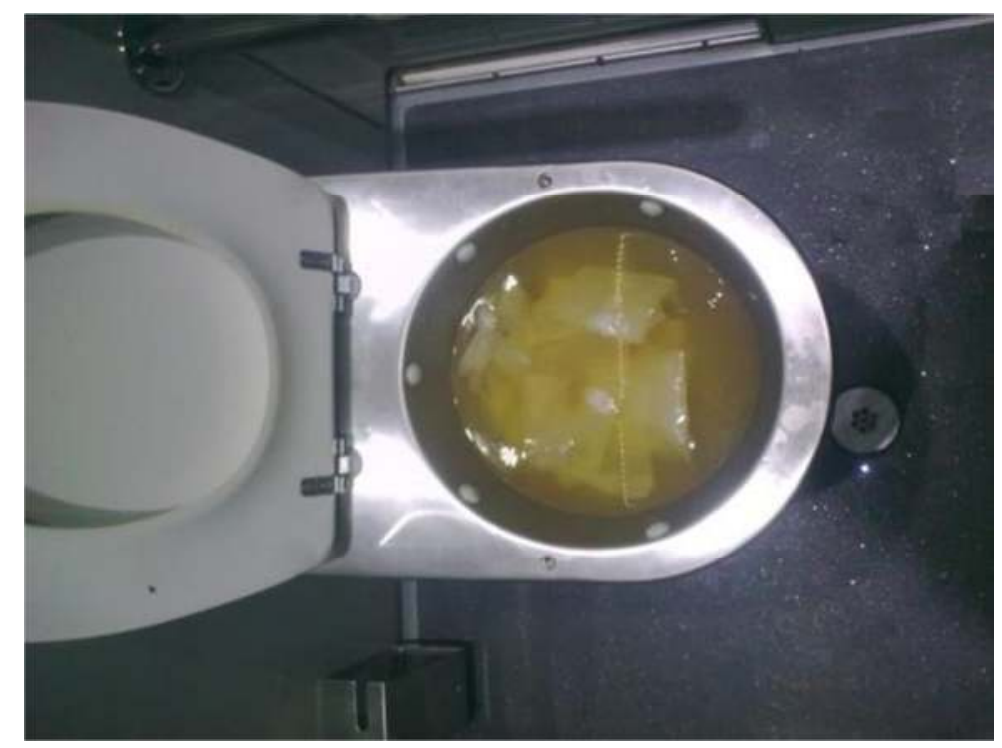

30. Clogged vacuum toilet on the train

The next problem is closing the toilet doors. This is often signaled by the operating system (Fig. 31). In vehicles equipped with electronic locks, mechanisms wear out very often, after many years of use, and as a result, very embarrassing situations arise. This is where one passenger goes to the toilet to use them. He enters and presses the door locking button or, in another variant of the lock design, turns the mechanical lock. Then he goes to the toilet bowl to use it. At the same time, due to the train running on the track, junctions, vibrations unlock the electronic and mechanical lock. The bolt rotates about 10 degrees (fig. 32-33). A green signal is displayed on the external toilet occupancy signal - free. The second passenger, outside seeing the green light, thinks - free. He presses the door release button and ... finds the first passenger naked above the toilet (sic).

From the passenger's point of view, it is not important who produced the rolling stock, but the quality of its manufacture and maintenance. Such situations indicate the cheap execution of components and the lack of the so-called technical culture of the website. The complete failure to take into account the wear processes at the design stage of the toilet in the selection of materials and the implementation of their elements proves the lack of education of designers. Lack of service proves bad planning of the renovation plan. 


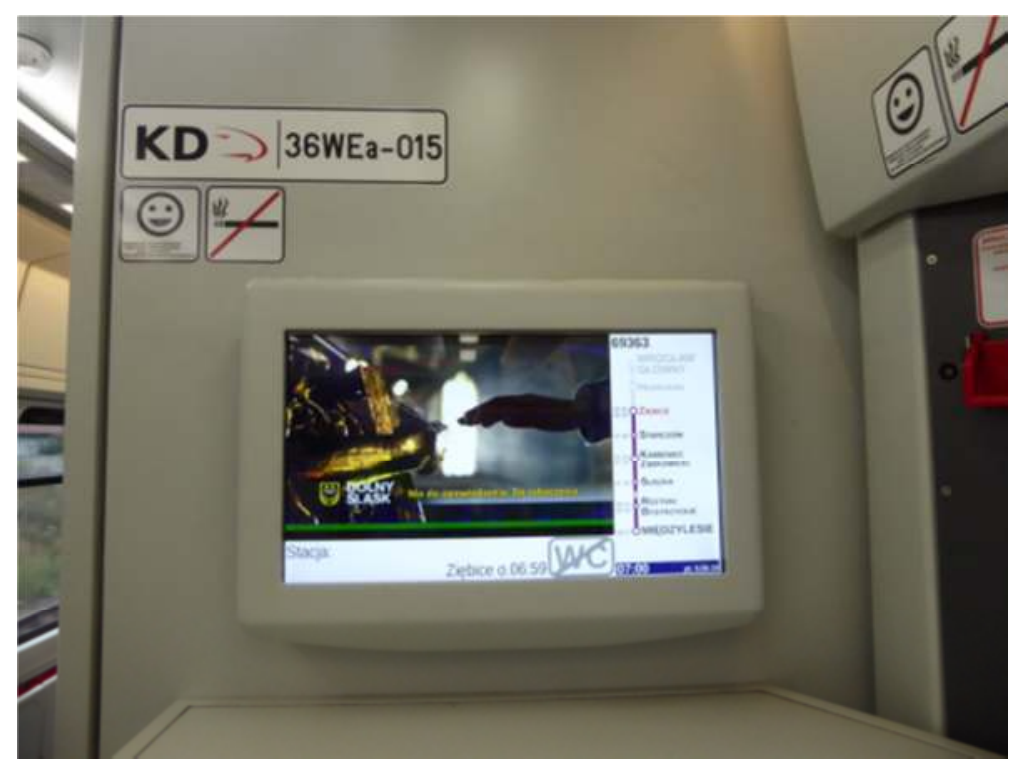

31. Train toilet door regurgitation signal

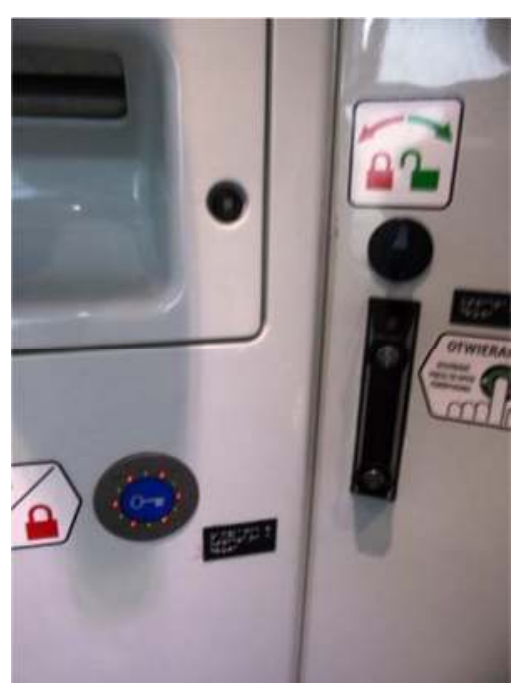

32. Blocked toilet door

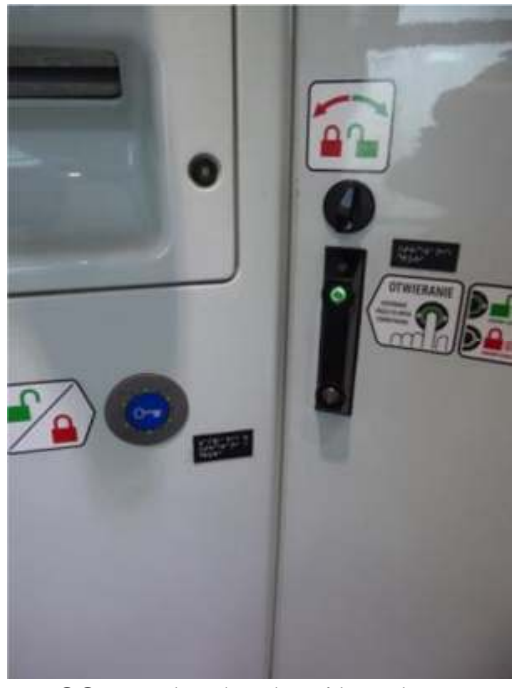

33. Unlocked toilet door 
It is reasonable for each carrier to standardize the toilet door locking system. The best for classic, mechanical locking with bolt locks and electric sliding doors for disabled cabins. For small toilets, locks with a mechanical lock and manual door opening are best. This is a measurable benefit for the passenger. He does not have to guess how it is handled when the rolling stock is replaced. There is also a measurable economic benefit for the carrier. Uniform type = lower costs. In addition, it reduces its risk of exposure to compensation payments to passengers for violating transport law.

\section{Review of the law on toilets in trains}

In Poland, health and safety regulations for workplaces should be the reference point. It follows that there is no uniform regulation of the President of UTK or the competent minister responsible for railways.

Health and safety regulations for buildings include that there is an obligation to install toilets on each floor, not more than $75 \mathrm{~m}$ from the workplace, and in proportion to the expected number of female and male workers. At least 1 toilet is separate for every 20 women and 30 men. If it is so that the employees are women and men, then this proportion is used [15][26]:

Tab. 1. Employee sanitary facilities for women and men

Number of employees Number of toilet cubicles and washbasins

$\begin{array}{cc}1-5 & 1 \\ 6-25 & 2 \\ 26-50 & 3 \\ 51-75 & 4 \\ 76-100 & 5\end{array}$

The main document that describes the leaf requirements of toilets and the technical requirements for them, for new and modernized vehicles, is the EU Commission Decision of December 21, 2007 and the UIC 563 Charter.

COMMISSION DECISION of 21 December 2007 concerning the technical specification for interoperability relating to the "Persons with reduced mobility" aspect of the trans-European conventional rail system and the trans-European high-speed rail system [4] defines the concepts of a standard and universal toilet for wheelchair users and the equipment of a universal toilet cabin with a changing table for children, if there is no separate baby care room, it also determines the number of places for people in wheelchairs.

Tab. 2. Number of wheelchair spaces on the train

\begin{tabular}{|c|c|}
\hline Train length & Number of wheelchair spaces on the train \\
\hline less than 205 meters & 2 wheelchair spaces \\
\hline 205 to 300 meters & 3 wheelchair spaces \\
\hline greater than 300 meters & 4 wheelchair spaces \\
\hline
\end{tabular}


highest legal authority in the region is the provincial government operating under the name of the Marshal's Office. It is responsible for organizing the rules of public transport on the railroad. As a result, in each voivodeship, there are different rules for ordering rolling stock and equipping it with the number and type of toilets. Therefore, it makes sense to develop rules for the design and modernization of rolling stock taking into account the minimum number of toilets on board.

In UIC 563 Sanitary and cleaning equipment of passenger carriages [8], it is written as follows: each vehicle intended for the transport of passengers must be equipped with at least 1 toilet (one). A car with seats for more than 40 passengers must be equipped with 2 (two) toilets. Each toilet must have a washbasin. Therefore, it must be concluded that the used vehicles do not fulfill this condition. They require adaptive renovation

\section{Legal regulation proposal}

The topic of toilets in public places is marginal. Nevertheless, everyone who reads this article is human. And that means that he is eating, drinking and... expelling. It is not necessary to make complicated theoretical arguments to state that each person has used and will use toilets at some point in public transport. Such are passenger trains.

It is reasonable that the president of UTK, through the competent minister, issues an ordinance by the act on compulsory planning of the layout and type of toilets in trains and their maintenance by the carrier.

1. The subject of the act is to regulate the number, type and equipment of toilets in passenger rail vehicles, such as: trailer carriages for locomotives and diesel, electric or hybrid multiple units.

2. The term toilet is understood as a separate room closed with a door with a lock, called a cabin, as well as a toilet bowl, washbasin, dustbin, and a changing table for babies with appropriate labeling and equipment..

3. There are also toilets intended for disabled people in wheelchairs or on crutches.

4. Regulation of the number of toilets:

4.1. for new or modernized vehicles

1) 1 toilet cubicle should be installed on each wagon or member of a train set.

2) In each train composed of trailed carriages and each trainset, one cabin for the disabled should be installed with appropriate markings near the places for people in wheelchairs.

4.2. for other vehicles

1) Historic, i.e. entered in the register of movable monuments, in accordance with the original buildings

2) It is recommended to modernize the traction units and comply with Art. 4.1. paragraph. 1) and art. 4.2.2.6. and 7.3.2.7. (OJ L 064, 7.3.2008; 2008/164 / EC), or, failing that, withdrawal and cassation,

3) Trailed wagons, it is recommended to modernize and comply with Art. 4.1. paragraph. 2) and art. 4.2.2.6. and 7.3.2.7. (OJ L 064, 7.3.2008; 2008/164 / EC), or, failing that, withdrawal and cassation.

5. Dimensions and equipment of toilets

5.1. standard cabins must comply with UIC 563 A OR card Sanitary and cleaning equipment in passenger carriages

5.2. universal cabins must comply with Art. 4.2.2.6. (OJ L 064, 7.3.2008; 2008/164 / $\mathrm{EC})$,

6. Maintenance

Each licensed carrier is obliged to maintain toilets in their passenger trains in such a way that: 
1) before each departure of the train or car on the route, the permeability of the toilet and washbasins must be checked and the bins with rubbish emptied. In the event of an obstruction, the drain pipes must be unblocked. It is unacceptable to leave a train with an inaccurate toilet for each route. Empty the toilet faecal tank if the fill indicator shows more than $50 \%$ full;

2) Before each departure of a train or car on the route, the condition of the water tank for the toilet and washbasin must be checked. You should fill the water tank for the toilet and sink if the filling indicator shows less than 50\%;

3) before each departure of the train or car, the toilet must be cleaned and washed and the system of closing the door to the toilet cabin checked;

4) the cabin crew should be trained to check the condition of the toilet and be trained to start the unblocking process with increased suction pressure. It is recommended that no one is in the toilet cubicle during this time;

5) the carrier must empty the faeces tanks after the end of the daily circulation of the vehicle, regardless of its filling level, and refill the water for the toilet and washbasin, regardless of its emptying status;

6) the carrier must comply with the recommendations of sub-section 1 and 2 point 6 ;

7) In the event of insufficient service or the passenger being exposed to difficulties in using the toilet, the carrier is subject to administrative penalties.

\section{Summary}

Every rail passenger would like to have a quick and comfortable journey. The convenience of the train is not only wi-fi, air conditioning, or good suspension that does not give you the feeling of vibrations while driving. It is worth for the designers of passenger rolling stock to see that this rolling stock is used by healthy passengers, but also passengers with the problem of UI- urinary incontinence. Convenience is also the possibility of personal comfort. This is what access to a toilet is It is reasonable to start a discussion about the standard of the number of toilets in trains, their number and the standard of maintenance. This should not depend on the will of the contracting authority of the local self-government, as it has been so far, but it should result from regulations. In addition, each carrier should have one standard of closing the toilet door, so that the passenger would not have to guess how it is done in the new type. It is reasonable for each carrier to standardize them as part of the expected major repair that awaits each vehicle. The case, although not very popular, is absolutely factual.

\section{Source materials}

[1] American Silversmiths: Richard Imlay (1784-1867), Wm Erik Voss 2005, https://www.americansilversmiths.org/makers/silversmiths/182437.htm

[2] Bianculli Anthony J.: Trains and Technology: Cars, University of Delaware Press, 2001, p.18-19

[3] CAR-BUILDING, Appletons' annual cyclopædia and register of important events of the year. s., v. 13n o 28 (1888).p.128-133

[4] Decyzja komisji z dnia 21 grudnia 2007 r. dotycząca technicznej specyfikacji interoperacyjności w zakresie aspektu „Osoby o ograniczonej możliwości poruszania się" transeuropejskiego systemu kolei konwencjonalnych i transeuropejskiego systemu kolei dużych prędkości (notyfikowana jako dokument nr C(2007) 6633) (Tekst mający znaczenie dla EOG)(2008/164/WE), (Dz.U. L 064, 7.3.2008, p.72)

[5] Dokumentacja systemu utrzymania jednoczłonowego autobusu szynowego typu $213 \mathrm{M}$ serii SA105. kolejewlkp.pl.

[6] Dokumentacja systemu utrzymania dwuczłonowego autobusu szynowego typu 215M serii SA108. kolejewlkp.pl 
[7] Geistbeck Michael: Der Weltverkehr. : Telegraphie und Post, Eisenbahnen und Schiffahrt, in ihrer Entwickelung dargestellt, HerderscheVerlagshandlung,1895r, Str 199.

[8] Karta UIC 563 Urządzenia sanitarne i porządkowe wagonów pasażerskich, Fittings provided in coaches in the interests of hygiene and cleanliness, Installation d'hygiène et de propreté des voitures, zał. 2 , str. 6 p. 1.1. General conditions

[9] Kotlarek A.: Kolej Gór Izerskich, https://swieradowzdroj.pl/upload/pdf/2290/kolejgrizerskich.pdf

[10] Madrjas Jakub: Imitacja drewna i przestrzeń dla dzieci. Zobacz wnętrza Linka dla PolRegi, 27.04.2017 https://www.rynek-kolejowy.pl/mobile/imitacja-drewna-iprzestrzen-dla-dzieci-zobacz-wnetrza-linka-dla-polregio-81494.html

[11] Ogurek O.: Postępy motoryzacji na Polskich Kolejach Państwowych i możliwości jej rozwoju, Inżynier Kolejowy, 9/1936, p. 313-326

[12] Pesa - Dokumentacje Systemu Utrzymania: 218Mb KD

[13] Popular Mechanics 2/1905r, str 217: Gasoline Motor Car For English Railways,

[14] Popular Mechanics 7/1909r., str 24: Double Electric Cars Of Self-Contained Type,

[15] Rozporządzenie Ministra Infrastruktury w sprawie warunków technicznych, jakim powinny odpowiadać budynki i ich usytuowanie. z dnia 12 kwietnia 2002 r. (Dz.U. 75, poz. 690)

[16] Rozporządzenie Ministra Pracy i Polityki Socjalnej z dnia 26 września 1997 r. w sprawie ogólnych przepisów bezpieczeństwa i higieny pracy. (Dz.U. nr 129 poz. 844)

[17] Spalinowe Zespoły Trakcyjne 220M/221M, newag.pl

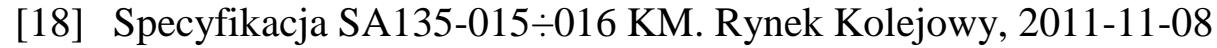

[19] Urząd Marszałkowski Województwa Zachodniopomorskiego: Spalinowy zespół trakcyjny autobus szynowy 219M serii SA136

[20] US Patent 389A: RICHARD IMLAY, Mode of supporting the bodies of railroad-cars and carriages, 1837-09-21,

[21] Wagony spalinowe obcych zarządów obsługujące połączenia transgraniczne. W: Robert Kroma, Janusz Sosiński, Krzysztof Zintel: Normalnotorowe wagony silnikowe kolei polskich 1991-2013. Wyd. Poznań: BWH Kolpress, 2014, s. 297-307, seria: Encyklopedia taboru. ISBN 978-83-933257-6-4.

[22] WATKINS J. E.: EVOLUTION OF THE RAILWAY PASSENGER CAR., Harper's weekly. v.32 1888. P.641-844

[23] White John H.: The American Railroad Passenger Car, JHU Press, 1985, p.12-13

[24] Zbyněk Zlinský: Motorové vozy na našich kolejích: řada 810, vlaky.net, 25.11.2007, https://www.vlaky.net/zeleznice/spravy/002160-Motorove-vozy-na-nasich-kolejichrada-810.asp 